Factors associated with

central obesity in adults from

Florianópolis, Santa Catarina: a

population based-study

\section{Fatores associados à obesidade central em adultos de Florianópolis, Santa Catarina: estudo de base populacional}

Thiago Ferreira de Sousa ${ }^{1,11}$

Markus Vinicius Nahas',"I

Diego Augusto Santos Silva'

Giovâni Firpo Del Duca',"1

Marco Aurélio Peres"'I

' Programa de Pós-Graduação em Educação Física da Universidade Federal de Santa Catarina (UFSC); Centro de Desportos (CDS) de Florianópolis, SC.

"Núcleo de Pesquisa em Atividade Física e Saúde (NuPAF) da Universidade Federal de Santa Catarina (UFSC); Centro de Desportos de Florianópolis, SC.

III Programa de Pós-Graduação em Saúde Pública da Universidade Federal de Santa Catarina (UFSC); Centro de Ciências da Saúde (CCS) de Florianópolis, SC.

\section{Abstract}

Objective: To estimate the prevalence of central obesity and its association with socio-demographic factors and health-related behaviors among adults from Florianópolis, State of Santa Catarina, Southern Brazil. Methods: A cross-sectional populationbased study was carried out in a sample of 1,720 adults between 20 to 59 years of age, residents in the urban area of the city. The outcome was the central obesity which was defined as a waist-height ratio $\geq 0.50$. Unadjusted and adjusted models were performed by using Poisson regression allowing estimation of the Prevalence Ratio (PR). All analyses were stratified by sex. Results: The prevalence of central obesity was $50.5 \%$ (95\% CI: 46.6-54.4) among men and 38.9\% (95\% CI 34.4-43.5) among women. In the adjusted analysis, central higher prevalence of obesity was observed in women aged 50 to 59 years and those who were living with a partner; lower prevalences were observed among women with $\geq 12$ years of study (PR: 0.63; 95\% CI: 0.47-0.85) and among those with higher income (PR: 0.64; 95\% CI: 0.470.86). Among men, a higher prevalence of central obesity was associated with ages 50 to 59 years and among those who were living with a partner, while a lower prevalence was identified in those in the highest income group. Conclusion: The prevalence of central obesity was high in the population studied. Demographic and socioeconomic factors were strongly associated with central obesity in both sexes. The knowledge of factors associated with central obesity may help the implementation of health interventions in order to prevent this core issue in Public Health.

Keywords: Obesity. Central obesity. Waistheight ratio. Health behavior. Adults. Crosssectional studies.

Fonte financiadora: Conselho Nacional de Desenvolvimento Científico e Tecnológico (CNPq), sob o número de 485327/2007-4 - Edital Universal 2007.

Correspondência: Thiago Ferreira de Sousa. Coordenadoria de Pós-Graduação em Educação Física, Campus Universitário, Bairro Trindade, Florianópolis, SC, CEP 88040-900. E-mail: tfsousa_thiago@yahoo.com.br 


\section{Resumo}

Objetivo: Estimar a prevalência e os fatores sociodemográficos e comportamentais associados à obesidade central em adultos de Florianópolis, Santa Catarina. Métodos: Pesquisa de delineamento transversal de base populacional com amostra de 1.720 adultos de 20 a 59 anos. A obesidade central foi avaliada pela razão entre as medidas da cintura e estatura, sendo considerada como acima do recomendável $\geq 0,50$. A Regressão de Poisson foi utilizada para estimar Razões de Prevalência (RP) nas análises brutas e multivariável entre a obesidade central e os indicadores sociodemográficos e comportamentos relacionados à saúde. Todas as análises foram estratificadas por sexo. Resultados: A prevalência de obesidade central foi de 50,5\% (IC 95\%: 46,6-54,4) para os homens e 38,9\% (IC 95\%: 34,4-43,5) para as mulheres. Após a análise multivariável, maiores prevalências de obesidade central foram observadas para as mulheres com faixa de idade de 50 a 59 anos e aquelas que vivem com companheiro(a) e, com menores prevalências, para as mulheres com escolaridade maior e igual a 12 anos (RP: 0,63; IC 95\%: 0,47-0,85) e maior renda (RP: 0,64; IC 95\%: 0,47-0,86). Para os homens, maiores prevalências foram evidenciadas com a faixa de idade de 50 a 59 anos, que vivem com companheiro(a) e com menor renda. Conclusão: A prevalência de obesidade central foi elevada nesta população e as variáveis demográficas e socioeconômicas foram fortemente discriminantes da prevalência de obesidade central em ambos os sexos. $\mathrm{O}$ conhecimento dos fatores associados à obesidade central pode orientar as intervenções dirigidas à prevenção deste importante problema de saúde pública.

Palavras-chave: Obesidade. Obesidade Central. Razão cintura-estatura. Conduta de saúde. Adultos. Estudos transversais.

\section{Introduction}

Obesity, defined as the accumulation of body fat above recommended levels, represents a public health problem on a worldwide scale and is strongly linked with diverse non-transmissible chronic diseases $^{1}$. In international studies, prevalence of obesity (body mass index (BMI) above $30 \mathrm{~kg} / \mathrm{m}^{2}$ ), ranges from $15.7 \%$ in Zimbabwe to $32.2 \%$ in the United States in adults of all ages $^{2}$. In Brazil, an increase in prevalence of obesity in adults has been observed, with prevalence of $2.8 \%$ and $12.4 \%$ in men during the period from 1974 and 2009, respectively, and from $8.0 \%$ and $16.9 \%$ in women during the same period. In 2009, the southern region of the country presented a higher prevalence of obesity when compared to other regions of the country ${ }^{3}$.

The estimates of obesity for the detection of health risks are more frequently reported by the BMI. However, it is known that central obesity, defined as the concentration of fat in the abdominal region, presents a greater predictive sensitivity of diseases and health problems ${ }^{4}$. Among the central obesity indicators ${ }^{5}$, the waist-to-height ratio (WHtR) has shown itself to be more sensitive in the prediction of health risks than the waist perimeter ${ }^{6,7,8}$.

The WHtR presents as advantages a similar cut-off point between the sexes, between different ethnic groups and age ranges ${ }^{6}$. Average WHtR scores in adults from the city of Salvador, (Bahia, Northeast Brazil) were 0.51 and 0.53 for men and women, respectively ${ }^{8}$, lower than the average scores observed in adults in the United States of America which were 0.56 in men and 0.57 in women ${ }^{9}$. In studies developed in other countries, averages higher than these rates stand out depending on an increase in age ${ }^{10,11}$, among those who do not practice physical exercise, have high blood pressure and high levels of triglycerides and glycemia $^{10}$.

The purpose of the current study was to determine the prevalence and the sociodemographic and behavioral factors asso- 
ciated with central obesity in adults from Florianópolis, Santa Catarina.

\section{Methods}

This study is derived from the population-based EpiFloripa Adultos 2009, a research conducted on a representative sample of adults from the urban area of Florianópolis, Santa Catarina. The aim of this study was to investigate self- assessment of health, self-rated morbidities, oral health, utilization of health services and main risk factors for chronic diseases such as demographic and socioeconomic characteristics, alimentary habits, practice of physical activities, blood pressure, anthropometric indicators, problematic use of alcohol and tobacco consumption. The study was realized in Florianópolis, the capital of the state of Santa Catarina. The estimated population in 2009 was 408,161 inhabitants ${ }^{12}$. Data collection occurred between September 2009 and January 2010 and the target population of the study $(\mathrm{N}=$ 249.530) comprised adults between 20 and 59 years of age, residents of the urban area of the city. This age range accounted for approximately $60 \%$ of the total municipal population in $2009^{12}$.

To estimate the necessary sample size, the Epi-Info program was used, version 6.04, publically available ${ }^{13}$. The equation was used to calculate prevalence considering the following parameters: target population of 249.530 individuals, confidence level of 95\%, unknown prevalence outcomes of $50 \%$, sample error of 3.5 percentage points, an estimated design effect (deff) of 2, percentage (\%) of losses estimated at $10 \%$ and $15 \%$ for control of confounding factors in studies of association. Through application of these parameters, a sample of 2,016 people was obtained.

Considering the study parameters of statistic power as $80 \%$, confidence level of $95 \%$ and number of subjects in each category of independent variables, this study can detect prevalence ratios above 1.7 and below 0.6 in men and 1.3 and 0.8 in women, respectively, as factors of risk and protection in the unadjusted analysis.

Sample selection was carried out in two stages: in the first, the 420 urban sector tracts were stratified according to the income deciles of the head of the family ( $\mathrm{R} \$ 192,80$ a $\mathrm{R} \$ 13.209,50$; one US\$ worth 1.7 Reais -Brazilian currency)-at the time of data collection) and 60 sectors were selected by drawing lots systematically (fraction of sampling equal to seven), making up six sectors in each decile; in the second stage, the units were the households. For this stage the number of households in each census were updated. Study supervisors (postgraduate staff from department of Public Health, Physical Education and Nutrition from the Federal University of Santa Catarina) counted all the occupied households in the selected tracts (number of occupied households ranged from 61 to 810). The urban sector tract started from the furthest lower right point and ran clockwise.

In order to lower the coefficient of variation between the number of households of the census tracts to allow for a self-weighted sample, the sectors were reorganized through fusion and division of the units. This led to a reduction in the initial variation coefficient of $55 \%$ ( $n=60$ sectors) to $32 \%$ ( $n=63$ sectors). In this way, of the 16,755 households mapped out in the 63 sectors of the sample, 18 residences were randomly selected systematically (selection interval equal to 13) in each of the sectors, totaling 1,134 selected residences. Losses were recorded when adults were not located at the visited residence in at least four attempts, at different times and on different days during the week and at least once at the weekends and at night. A refusal was given when the resident declined to cooperate.

Data was collected through face to face interviews with all adult residents in the selected households by 35 selected interviewers, all having completed high school, and with full-time availability to carry out field work activities. The interviewers were trained prior to commencement of the research by the team responsible for the study. 
This comprised coordinators and supervisors of the study and technicians from the Brazilian Institute of Geography and Statistics. The interviewers were also trained by Physical Education professionals to perform the anthropometric measurements and the intra examiner and inter examiner ${ }^{14,15}$ reliability technical errors were calculated by each measurement being done twice consecutively on 10 adults.

Comprehension of the questionnaire was pre-tested by applying it on 30 adults in the same age range in a catchment area of a local health center. After training of the interviewers was complete, a pilot study was carried out on approximately 100 people in a census tract selected for this purpose. Results of this were not incorporated into the overall study.

The interviews were performed using 35 Personal Digital Assistants (PDAs) and lasted approximately one hour on average (slightly less for men). Use of this equipment minimized possible typing errors and facilitated checking of possible incoherencies during the data collection period. Quality control of the study was realized through a telephone interview with approximately $15 \%$ of the sample ( $n=248$ ), using a shortened version of the questionnaire containing 10 questions. Subsequently, the Kappa tests were applied to the categorical variables (nominal and ordinal) and IntraClass Correlation Coefficient for the continuous and discrete quantitative variables in order to calculate the reproducibility.

\section{Outcome}

The dependent variable of the current study was central obesity, defined by the waist-to-height ratio (WHtR). By dividing the circumference of the waist $(\mathrm{cm})$ by the height $(\mathrm{cm})$, adults were categorized as obese with WHtR scores $\geq 0.50$ with the same cut-off point for both men and women. To assess WHtR, procedures proposed by Lohman et al. ${ }^{16}$ were adopted. The waist circumference was measured with a nonextendable anthropometric tape by Sanny ${ }^{\circledR}$, with a $1 \mathrm{~mm}$ resolution, considering the smallest circumference, or, when this was unobserved, midway between the uppermost border of the iliac crest and the lower border of the costal margin.

To measure height, a stadiometer with a $1 \mathrm{~mm}$ metric tape was built. The participant was placed on a flat base in the orthostatic position and asked to take a deep breath. At this moment, the height measurement was taken from the top of the head. The adults who were unable to remain in the recommended position, pregnant women at the time of the research or who had given birth in the six months prior to the research did not have their anthropometric measurements taken ${ }^{17}$. The maximum relative technical error values observed during training for the waist circumference (intra-examiner 1.18; inter-examiner 1.86) and height (intra examiner 0.24 ; inter examiner 1.67 ) were considered satisfactory, according to recommendations by Gore et $a l^{15}$.

\section{Exploratory Variables}

For analysis purposes, the variables were categorized in the following way: sex (male and female), age range in completed years (20 to 29 years, 30 to 39 years, 40 to 49 years and 50 to 59 years), marital status (with a partner and without a partner, self-referred skin color, classified as white, brown and black (participants who referred to their skin color as yellow or indigenous were excluded due to the low number, $\mathrm{n}=17 \mathrm{e}$ 20 respectively), schooling in successfully completed years of study ( 0 to 4 years, 5 to 8 years, 9 to 11 years and $\geq 12$ years) and per capita family income in reais $\left(1^{\circ}\right.$ tertile $=$ up to $\mathrm{R} \$ 566.90 ; 2^{\circ}$ tertile $=\mathrm{R} \$ 567.00$ to 1300.00 ; and $3^{\circ}$ tertile $=\mathrm{R} \$ 1300.10$ to $33.333,00$ ).

The variables relative to health-related behaviors were categorized as the following: physical activity, dichotomized as no (refers to not having practiced any physical activities during leisure time in the last three months at least once a week, to not have walked or ridden a bicycle part of the way or the whole way, to school or work, refers to 
not walking enough or lifting enough weight at work and not being responsible for heavy housework) and yes (do physical activities, get around, work outside and in the home ${ }^{18}$; regular consumption of fruit: consumption $\geq 5$ days per week and consumption $\leq 4$ days per week $^{19}$; regular consumption of vegetables (lettuce and tomato salad or any raw vegetable or greens and cooked greens or vegetables like cabbage, carrot, chayote, eggplant, zucchini, except potato, cassava or yam): consumption $\geq 5$ days per week and consumption $\leq 4$ days per week ${ }^{19}$; problematic use of alcohol: standardized AUDIT score (The Alcohol Use Disorders Identification Test), proposed by the World Health Organization ${ }^{20}$, dichotomized as no (score 0 to 7) and yes (score $\geq 8$ ).

Data analysis was carried out in Stata 9.0 and descriptive analyses were realized through calculation of prevalence (categorical variables nominal and ordinal) and means, medians and standard deviation (SD) for the continuous and discrete variables of the study. Poisson Regression was used to estimate Prevalence (PR) in the adjusted and unadjusted analyses and Confidence Level of 95\% (CI95\%).

The following hierarchical model ${ }^{21}$ was adopted considering the hypothetical temporal relationship between the variables for the multivariable analysis, following the selection of using backward variables selection: the demographic variables at the distal level (age range and self-referred skin color), socioeconomic variables ( $p e r$ capita income and schooling level) and marital status at intermediary level and, at the proximal level, the variables of healthrelated behaviors (physical activity, regular consumption of fruit and vegetables and, problematic use of alcohol). All the variables were included in the multivariable analysis, independent of its $p$ value in the unadjusted analysis, following the theoretical hierarchical model. In order to choose selection method of the variables entrance in the multivariable model, we tested both forward and backward. A similarity was observed in the results between the methods for women although, for men, the income variable presented a differentiated characteristic, maintaining association with the outcome with the use of the backward method.

Adjustments were made to the variables of the same level and those which presented a $p$ value $\leq 0.20$ on the Wald test remained in the model. All the analyses were carried out taking the design effect (clusters) into account ("svy" command in Stata for analysis of complex samples) and stratified by sex. The significance value adopted was 5\%. The EpiFloripa Adultos 2009 project was approved by the Committee of Ethics in Research on Human Beings at the Federal University of Santa Catarina under protocol number 351/08. Informed consent was obtained from all participants and these were informed of the objectives of the study.

\section{Results}

The number of participants in the study was 1,720 adults ( $85.3 \%$ response rate) with a mean age of 38.1 years $(S D=11.6)$ and median of 38 years. The design effect (deff) for the outcome of this study (central obesity) was 2.25 and the intra-class correlation coefficient between obesity and the census tracts was 0.05 .

A higher proportion of women was observed between 20 and 29 years, white skin color, schooling equal to or greater than 12 years, lower per capita income ( $1^{\circ}$ tertile) and living with a partner. In relation to health-related behaviors, it was observed that in women, $11.2 \%$ do not practice physical activity, almost $10 \%$ present problematic use of alcohol and $40.6 \%$ present low consumption of fruit and approximately $37 \%$ have a lower consumption of vegetables than five days (Table 1). For men, a higher frequency was observed in the 20 to 29 age range, white skin color, schooling equal to or greater than 12 years and living with a partner. For health-related behaviors, $12.9 \%$ did not practice physical activity, a third presented problematic use of alcohol, more than half claimed to consume fruit four days a week or less and $45 \%$ claimed their consumption 
of vegetables to be equal to or less than four days a week (Table 1).

The mean value observed for central obesity was $0.50(\mathrm{SD}=0.01)$ and the median was 0.49 , being the mean value of 0.50 $(\mathrm{SD}=0.09)$ and median of 0.48 for women and mean of $0.51(\mathrm{SD}=0.07)$ and median of 0.50 for men. The proportion of adults with central obesity was $44.0 \%$ (95\%CI 40.5 - 47.8), higher for men when compared to women, $50.5 \%$ (95\%CI $46.6-54.4)$ and $38.9 \%$ (95\%CI 34.4 - 43.5), respectively (Table 2). Other information on prevalence of central obesity according to sociodemographic and behavioral variables is presented in Table 2.

In relation to women, the following factors were observed in the unadjusted analysis to be associated with the highest prevalence of central obesity: higher age ranges, having a partner and with lower prevalence of central obesity, higher per capita income, lower schooling level, fruit consumption lower than five days and problematic use of alcoholic beverages (Table 3). In the multivariable analysis, women of a higher age and those who live with a partner remained associated with the outcome. Higher schooling level and higher per capita income presented a lower prevalence when associated with the outcome (Table 3 )

For men, in the unadjusted analysis the following were associated with the outcome with higher prevalence: more advanced in age, living with a partner and not practicing physical activity; with lower prevalence were higher schooling levels (Table 4). In the multivariable analysis, advanced age and living with a partner remained associated with the greatest prevalence of the outcome. Men with higher per capita income had lower prevalence of central obesity after adjusting for other demographic and economic variables (Table 4 ).

In relation to prevalence of central obesity measured by the abdominal circumference in adults in Florianópolis, it was observed that the prevalence with a higher circumference (men $\geq 102 \mathrm{~cm}$ and women $\geq 88 \mathrm{~cm}$ ) was $16.4 \%$ (95\%CI: $13.8-18.3$ ), being higher in women (19.7\%; 95\%CI: $16.7-23.0)$ when compared to men $(11.6 \%$; 95\%CI: $9.3-14.3$ ). The same analysis model used for the WHtR was adopted for the abdominal circumference. Higher prevalence was observed in older women, those living with a partner and those with lower per capita income. For men, greater prevalence of high waist circumference was observed in older men and those with lower per capita income (data not presented).

\section{Discussion}

This study presents, as an important methodological characteristic, the use of WHtR for measuring central obesity, as this presents greater predictive sensitivity to cardiovascular risks ${ }^{7,8}$, diabetes mellitus ${ }^{22}$ and high blood pressure ${ }^{22}$ than waist circumference. TheWHtR is an index that adjusts for waist circumference (discriminator of central obesity) by height and, consequently, minimizes incorrect evaluation of health risks in adults of different height. Studies have shown greater sensitivity of this index in discriminating obesity between the sexes, different age and ethnic groups ${ }^{6}$. In Brazil, population-based studies which usedWHtR to estimate central obesity were not found. Studies by Haun et al. ${ }^{8}$ and Pitanga e Lessa ${ }^{7}$ on adults in Salvador, Bahia, stand out which discriminated the predictive strength of WHtR to estimate cardiovascular risks.

The mean values of WHtR observed in the current study were lower (men: 0.51; women: 0.50 ) than the mean values of studies carried out on adults in the United States (men: 0.57; women: 0.56) ${ }^{9}$, Iraq (men: 0.53; women: 0.58$)^{23}$, Mexico (men: 0.58; women: $0.66)^{24}$ and Spain (men: 0.57 ; women: 0.61$)^{24}$. In relation to the mean values of WhtR in Brazilian adults from Salvador, Bahia, it can be seen that women presented a higher score than men, 0.53 and 0.51 , respectively ${ }^{8}$, which differ from observations made in this study. However, a tendency for a higher index of central obesity for men can be observed when information from other countries is analyzed using the $\mathrm{WhtR}^{9,24}$. For the popu- 
Table 1 - Socio-demographic characteristics and health-related behaviors overall and by sex in adults from Florianópolis, Santa Catarina, Brazil, 2009.

Tabela 1 - Descrição das características sociodemográficas e dos comportamentos relacionados à saúde de acordo como sexo e geral em adultos de Florianópolis, Santa Catarina, 2009.

\begin{tabular}{|c|c|c|c|c|c|c|}
\hline \multirow[b]{2}{*}{ Variables } & \multicolumn{2}{|r|}{ Females } & \multicolumn{2}{|r|}{ Males } & \multicolumn{2}{|r|}{ Overall } \\
\hline & $\mathrm{n}$ & $\%(95 \% \mathrm{Cl})$ & $\mathrm{n}$ & $\%(95 \% \mathrm{Cl})$ & $\mathrm{n}$ & $\%(95 \% \mathrm{Cl})$ \\
\hline & 959 & $55.8(53.8-57.6)$ & 761 & $44.2(42.3-46.1)$ & & \\
\hline \multicolumn{7}{|c|}{ Age ranges (completed years) } \\
\hline 20 to 29 years & 280 & $29.2(24.9-33.4)$ & 260 & $34.2(29.5-38.8)$ & 540 & $31.4(27.4-35.4)$ \\
\hline 30 to 39 years & 220 & $22.9(19.8-26.0)$ & 172 & $22.6(19.5-25.6)$ & 392 & $22.8(20.4-25.2)$ \\
\hline 40 to 49 years & 257 & $26.8(23.5-30.1)$ & 181 & $23.8(20.6-27.0)$ & 438 & $25.5(22.6-28.3)$ \\
\hline 50 to 59 years & 202 & $21.1(18.2-23.9)$ & 148 & $19.4(16.3-22.6)$ & 350 & $20.3(17.9-22.8)$ \\
\hline \multicolumn{7}{|l|}{ Skin color } \\
\hline White & 802 & $86.4(82.9-89.9)$ & 642 & $85.6(81.7-89.5)$ & 1.444 & $86.0(82.8-89.3)$ \\
\hline Brown & 73 & $7.9(5.6-10.1)$ & 74 & $9.9(6.8-12.9)$ & 147 & $8.8(6.5-11.0)$ \\
\hline Negro or black & 53 & $5.7(3.3-8.1)$ & 34 & $4.5(2.4-6.6)$ & 87 & $5.2(3.3-7.1)$ \\
\hline \multicolumn{7}{|l|}{ Schooling } \\
\hline 0 to 4 years & 89 & $9.3(6.7-11.8)$ & 69 & $9.1(6.4-11.8)$ & 158 & $9.2(6.8-11.6)$ \\
\hline 5 to 8 years & 145 & $15.1(12.2-18.1)$ & 108 & $14.2(11.3-17.2)$ & 253 & $14.7(12.1-17.4)$ \\
\hline 9 to 11 years & 305 & $31.8(27.9-35.8)$ & 263 & $34.7(29.5-39.8)$ & 568 & $33.1(29.1-37.1)$ \\
\hline$\geq 12$ years & 419 & $43.8(37.7-49.7)$ & 318 & $42.0(35.4-48.5)$ & 737 & $43.0(37.0-48.9)$ \\
\hline \multicolumn{7}{|l|}{ Marital status } \\
\hline No partner & 375 & $39.1(35.4-42.8)$ & 302 & $39.7(35.5-43.9)$ & 677 & $39.4(36.2-42.5)$ \\
\hline With a partner & 584 & $60.9(57.2-64.6)$ & 459 & $60.3(56.1-64.5)$ & 1.043 & $60.6(57.5-63.8)$ \\
\hline \multicolumn{7}{|c|}{$\begin{array}{l}\text { Per capita income in Reais } \\
\text { (Brazilian currency) }\end{array}$} \\
\hline $1^{\circ}$ tertile & 335 & $35.7(29.2-42.1)$ & 229 & $30.8(25.5-36.0)$ & 564 & $33.5(27.7-39.2)$ \\
\hline $2^{\circ}$ tertile & 304 & $32.3(28.7-36.0)$ & 258 & $34.6(30.5-38.7)$ & 562 & $33.3(29.9-36.8)$ \\
\hline $3^{\circ}$ tertile & 301 & $32.0(25.4-38.6)$ & 258 & $34.6(28.7-40.5)$ & 559 & $33.2(27.1-39.3)$ \\
\hline \multicolumn{7}{|l|}{ Physical activity } \\
\hline Yes & 850 & $88.8(85.9-91.7)$ & 657 & $87.1(84.3-89.9)$ & 1.507 & $88.1(85.7-90.4)$ \\
\hline No & 107 & $11.2(8.3-14.0)$ & 97 & $12.9(10.0-15.7)$ & 204 & $11.9(9.6-14.3)$ \\
\hline \multicolumn{7}{|l|}{ Fruit consumption } \\
\hline$\geq 5$ days per week & 569 & $59.4(55.9-62.9)$ & 316 & $41.5(37.6-45.4)$ & 885 & $51.5(48.6-54.3)$ \\
\hline$\leq 4$ days per week & 389 & $40.6(37.1-44.1)$ & 445 & $58.5(54.6-62.4)$ & 834 & $48.5(45.7-51.4)$ \\
\hline \multicolumn{7}{|c|}{ Vegetable consumption } \\
\hline$\geq 5$ days per week & 607 & $63.4(59.4-67.3)$ & 416 & $54.7(50.7-58.6)$ & 1.023 & $59.5(56.3-62.7)$ \\
\hline$\leq 4$ days per week & 351 & $36.6(32.7-40.6)$ & 345 & $45.3(41.4-49.3)$ & 696 & $40.5(37.3-43.7)$ \\
\hline \multicolumn{7}{|c|}{ Problematic use of alcohol } \\
\hline No & 870 & $90.7(88.3-93.1)$ & 533 & $70.0(66.1-73.9)$ & 1.043 & $81.6(79.0-84.1)$ \\
\hline Yes & 89 & $9.3(6.8-11.7)$ & 228 & $30.0(26.0-33.9)$ & 317 & $18.4(15.9-21.0)$ \\
\hline
\end{tabular}

$\%=$ Prevalence; $95 \% \mathrm{Cl}=95 \%$ Confidence interval. $/ \%$ = Prevalência $;$ IC95\% = Intervalo de confiança de $95 \%$. 
Table 2 - Prevalence of central obesity according to socio-demographic indicators and health-related behaviors overall and by sex in adults from Florianópolis, Santa Catarina, Brazil, 2009.

Tabela 2 - Prevalência de obesidade central de acordo com os indicadores sociodemográficos e dos comportamentos relacionados à saúde por sexo e geral em adultos de Florianópolis, Santa Catarina, 2009.

\begin{tabular}{|c|c|c|c|c|c|c|}
\hline \multirow[b]{2}{*}{ Variables } & \multicolumn{2}{|r|}{ Females } & \multicolumn{2}{|r|}{ Males } & \multicolumn{2}{|r|}{ Overall } \\
\hline & $\mathrm{n}$ & $\%(195 \% \mid C)$ & $\mathrm{n}$ & $\%(95 \% \mathrm{Cl})$ & $\mathrm{n}$ & $\%(95 \% \mathrm{Cl})$ \\
\hline & 918 & $38.9(34.4-43.5)$ & 750 & $50.5(46.6-54.4)$ & 1.668 & $44.0(40.5-47.8)$ \\
\hline \multicolumn{7}{|c|}{ Age ranges (completed years) } \\
\hline 20 to 29 years & 259 & $19.3(13.7-26.5)$ & 257 & $24.9(19.3-31.5)$ & 516 & $22.1(17.7-27.2)$ \\
\hline 30 to 39 years & 208 & $31.7(23.7-41.1)$ & 168 & $50.6(42.7-58.5)$ & 376 & $40.2(33.6-47.1)$ \\
\hline 40 to 49 years & 254 & $45.3(39.3-51.4)$ & 179 & $66.5(59.6-72.7)$ & 433 & $54.0(49.1-59.0)$ \\
\hline 50 to 59 years & 197 & $64.0(56.0-71.2)$ & 146 & $76.0(67.1-83.1)$ & 343 & $69.1(62.8-74.8)$ \\
\hline \multicolumn{7}{|l|}{ Skin color } \\
\hline White & 765 & $38.3(33.8-43.0)$ & 632 & $51.4(47.2-55.6)$ & 1.397 & $44.2(40.4-48.1)$ \\
\hline Brown & 72 & $37.5(27.3-48.9)$ & 73 & $43.8(35.0-53.1)$ & 145 & $40.7(32.8-49.1)$ \\
\hline Negro or black & 50 & $46.0(33.0-59.6)$ & 34 & $44.1(30.0-59.3)$ & 84 & $45.2(35.4-55.4)$ \\
\hline \multicolumn{7}{|l|}{ Schooling } \\
\hline 0 to 4 years & 88 & $71.6(60.5-80.5)$ & 67 & $67.2(54.3-77.9)$ & 155 & $69.7(61.0-77.2)$ \\
\hline 5 to 8 years & 138 & $52.9(44.1-61.6)$ & 108 & $57.4(47.9-66.4)$ & 246 & $54.9(48.6-61.0)$ \\
\hline 9 to 11 years & 291 & $39.9(33.9-46.2)$ & 260 & $51.9(44.8-59.0)$ & 551 & $45.5(40.5-50.7)$ \\
\hline$\geq 12$ years & 401 & $26.2(21.3-31.7)$ & 312 & $43.3(37.6-49.1)$ & 713 & $33.7(29.2-38.5)$ \\
\hline \multicolumn{7}{|l|}{ Marital status } \\
\hline No partner & 369 & $31.2(25.9-37.0)$ & 297 & $36.0(30.5-41.9)$ & 666 & $33.3(29.2-37.7)$ \\
\hline With a partner & 549 & $44.1(38.6-49.7)$ & 453 & $60.0(55.4-64.5)$ & 1.002 & $51.3(47.2-55.4)$ \\
\hline \multicolumn{7}{|c|}{$\begin{array}{l}\text { Per capita income in Reais } \\
\text { (Brazilian currency) }\end{array}$} \\
\hline $1^{\circ}$ tertile & 320 & $47.2(41.4-53.0)$ & 227 & $52.0(45.9-58.0)$ & 547 & $49.2(44.7-53.7)$ \\
\hline $2^{\circ}$ tertile & 291 & $41.2(33.9-49.0)$ & 254 & $55.9(49.2-62.4)$ & 545 & $48.1(42.8-53.4)$ \\
\hline $3^{\circ}$ tertile & 289 & $26.6(21.0-33.1)$ & 254 & $45.7(38.7-52.8)$ & 543 & $35.5(30.4-41.1)$ \\
\hline \multicolumn{7}{|l|}{ Physical activity } \\
\hline Yes & 820 & $38.4(33.7-43.3)$ & 650 & $48.6(44.3-52.9)$ & 1.470 & $42.9(39.2-46.8)$ \\
\hline No & 97 & $42.3(32.2-53.0)$ & 95 & $64.2(54.3-73.0)$ & 192 & $53.1(45.3-60.8)$ \\
\hline \multicolumn{7}{|l|}{ Fruit consumption } \\
\hline$\geq 5$ days per week & 542 & $42.1(36.6-47.7)$ & 311 & $53.0(46.7-59.3)$ & 853 & $46.1(41.4-50.8)$ \\
\hline$\leq 4$ days per week & 376 & $34.3(28.7-40.4)$ & 439 & $48.7(43.8-53.7)$ & 815 & $42.1(38.0-46.3)$ \\
\hline \multicolumn{7}{|c|}{ Vegetable consumption } \\
\hline$\geq 5$ days per week & 577 & $37.3(32.0-42.8)$ & 410 & $50.5(45.5-55.4)$ & 987 & $42.8(38.3-47.4)$ \\
\hline$\leq 4$ days per week & 341 & $41.6(35.5-48.0)$ & 340 & $50.6(44.7-56.5)$ & 681 & $46.1(41.5-50.8)$ \\
\hline \multicolumn{7}{|c|}{ Problematic use of alcohol } \\
\hline No & 829 & $40.7(36.5-45.2)$ & 528 & $51.1(46.5-55.8)$ & 1.375 & $44.8(41.4-48.6)$ \\
\hline Yes & 89 & $21.3(13.3-32.4)$ & 222 & $49.1(40.9-57.4)$ & 311 & $41.2(34.3-48.3)$ \\
\hline
\end{tabular}

$\%=$ Prevalence; $95 \% \mathrm{Cl}=95 \%$ Confidence interval. $/ \%$ = Prevalência $;$ IC95\% = Intervalo de confiança de $95 \%$. 
Table 3 - Association between central obesity and socio-demographic factors and health-related behaviors in adult women from Florianópolis, Santa Catarina, Brazil, 2009. Unadjusted and adjusted Prevalence Ratios (PR) estimated by the Poisson regression.

Tabela 3 - Associação entre obesidade central e variáveis sociodemográficas e comportamentos relacionados à saúde em mulheres adultas de Florianópolis, Santa Catarina, 2009. Razões de prevalência (RP) brutas e ajustadas estimadas por Regressão de Poisson.

\begin{tabular}{|c|c|c|c|c|c|c|}
\hline \multirow[b]{2}{*}{ Leve } & \multirow[b]{2}{*}{ Variables } & \multirow[b]{2}{*}{$\mathrm{n}$} & \multicolumn{2}{|c|}{ Unadjusted Analysis } & \multicolumn{2}{|c|}{ Adjusted Analysis $\$$} \\
\hline & & & PR $(95 \% \mathrm{Cl})$ & $\mathrm{p}$ & PR $(95 \% \mathrm{Cl})$ & $\mathrm{p}$ \\
\hline \multirow[t]{5}{*}{1} & Age ranges (completed years) & & & $<0.001^{*}$ & & $<0.001^{*}$ \\
\hline & 20 to 29 years & 259 & 1.00 & & 1.00 & \\
\hline & 30 to 39 years & 208 & $1.64(1.07-2.51)$ & & $1.64(1.06-2.54)$ & \\
\hline & 40 to 49 years & 254 & $2.34(1.67-3.28)$ & & $2.41(1.71-3.38)$ & \\
\hline & 50 to 59 years & 197 & $3.31(2.36-4.63)$ & & $3.46(2.47-4.84)$ & \\
\hline \multirow[t]{4}{*}{1} & Skin color & & & 0.31 & & 0.08 \\
\hline & White & 765 & 1.00 & & 1.00 & \\
\hline & Brown & 72 & $0.98(0.74-1.29)$ & & $1.04(0.80-1.35)$ & \\
\hline & Negro or black & 50 & $1.20(0.88-1.63)$ & & $1.26(0.97-1.64)$ & \\
\hline \multirow[t]{5}{*}{2} & Schooling & & & $<0.001^{*}$ & & $0.003^{*}$ \\
\hline & 0 to 4 years & 88 & 1.00 & & 1.00 & \\
\hline & 5 to 8 years & 138 & $0.74(0.60-0.91)$ & & $0.88(0.71-1.09)$ & \\
\hline & 9 to 11 years & 291 & $0.56(0.46-0.67)$ & & $0.84(0.67-1.07)$ & \\
\hline & $\geq 12$ years & 401 & $0.36(0.28-0.47)$ & & $0.63(0.47-0.85)$ & \\
\hline \multirow[t]{3}{*}{2} & Marital Status & & & $<0.001$ & & 0.02 \\
\hline & No partner & 369 & 1.00 & & 1.00 & \\
\hline & With a partner & 549 & $1.41(1.17-1.71)$ & & $1.20(1.02-1.42)$ & \\
\hline \multirow[t]{4}{*}{2} & $\begin{array}{l}\text { Per capita income in Reais } \\
\text { (Brazilian curreny) }\end{array}$ & & & $<0.001^{*}$ & & $0.004^{*}$ \\
\hline & $1^{\circ}$ tertile & 320 & 1.00 & & 1.00 & \\
\hline & $2^{\circ}$ tertile & 291 & $0.87(0.71-1.07)$ & & $0.92(0.75-1.13)$ & \\
\hline & $3^{\circ}$ tertile & 289 & $0.56(0.44-0.73)$ & & $0.64(0.47-0.86)$ & \\
\hline \multirow[t]{3}{*}{3} & Physical activity & & & 0.47 & & 0.74 \\
\hline & Yes & 820 & 1.00 & & 1.00 & \\
\hline & No & 97 & $1.10(0.84-1.43)$ & & $1.04(0.83-1.30)$ & \\
\hline \multirow[t]{3}{*}{3} & Fruit consumption & & & 0.03 & & 0.87 \\
\hline & $\geq 5$ days per week & 542 & 1.00 & & 1.00 & \\
\hline & $\leq 4$ days per week & 376 & $0.82(0.68-0.98)$ & & $0.98(0.81-1.20)$ & \\
\hline \multirow[t]{3}{*}{3} & Vegetable consumption & & & 0.24 & & 0.41 \\
\hline & $\geq 5$ days per week & 577 & 1.00 & & 1.00 & \\
\hline & $\leq 4$ days per week & 341 & $1.11(0.93-1.35)$ & & $1.08(0.90-1.30)$ & \\
\hline \multirow[t]{3}{*}{3} & Problematic use of alcohol & & & 0.003 & & \\
\hline & No & 829 & 1.00 & & 1.00 & 0.16 \\
\hline & Yes & 89 & $0.52(0.34-0.80)$ & & $0.76(0.52-1.11)$ & \\
\hline
\end{tabular}

1 = Distal level; 2 = Intermediate level; 3 = Proximal level. $/ 1$ = Nível distal; 2 = Nível intermediário; 3 = Nível proximal.

* Linear trend $\mathrm{p}$ value. / * $p$ valor para tendência linear.

$\$$ Adjusted for other variables of the same level or higher with a $\mathrm{p}$ value $\leq 0.20$. / $\$$ Ajustada para outras variáveis do mesmo nivel ou de nível superior com $p$ valor $\leq 0,20$. 
Table 4 - Association between central obesity and socio-demographic factors and health-related behaviors in adult men from Florianópolis, Santa Catarina, Brazil, 2009. Unadjusted and adjusted Prevalence Ratios (PR) estimated by the Poisson regression.

Tabela 4 - Associação entre obesidade central e variáveis sociodemográficas e comportamentos relacionados à saúde em homens adultos de Florianópolis, Santa Catarina, 2009. Razões de prevalência (RP) brutas e ajustadas estimadas por Regressão de Poisson.

\begin{tabular}{|c|c|c|c|c|c|c|}
\hline \multirow[b]{2}{*}{ Leve } & \multirow[b]{2}{*}{ Variables } & \multirow[b]{2}{*}{$\mathrm{n}$} & \multicolumn{2}{|c|}{ Unadjusted Analysis } & \multicolumn{2}{|c|}{ Adjusted Analysis $\$$} \\
\hline & & & PR $(95 \% \mathrm{Cl})$ & $p$ & PR $(95 \% \mathrm{Cl})$ & $p$ \\
\hline \multirow[t]{5}{*}{1} & Age ranges (completed years) & & & $<0.001^{*}$ & & $<0.001^{*}$ \\
\hline & 20 to 29 years & 257 & 1.00 & & 1.00 & \\
\hline & 30 to 39 years & 168 & $2.03(1.53-2.69)$ & & $2.03(1.53-2.69)$ & \\
\hline & 40 to 49 years & 179 & $2.67(2.01-3.53)$ & & $2.67(2.01-3.53)$ & \\
\hline & 50 to 59 years & 146 & $3.05(2.32-4.01)$ & & $3.05(2.32-4.01)$ & \\
\hline \multirow[t]{4}{*}{1} & Skin color & & & 0.18 & & 0.87 \\
\hline & White & 632 & 1.00 & & 1.00 & \\
\hline & Brown & 73 & $0.85(0.69-1.06)$ & & $0.92(0.75-1.12)$ & \\
\hline & Negro or black & 34 & $0.86(0.61-1.21)$ & & $1.09(0.78-1.51)$ & \\
\hline \multirow[t]{5}{*}{2} & Schooling & & & $<0.001^{*}$ & & $0.22^{*}$ \\
\hline & 0 to 4 years & 67 & 1.00 & & 1.00 & \\
\hline & 5 to 8 years & 108 & $0.85(0.65-1.12)$ & & $0.98(0.75-1.28)$ & \\
\hline & 9 to 11 years & 260 & $0.77(0.62-0.97)$ & & $1.03(0.84-1.27)$ & \\
\hline & $\geq 12$ years & 312 & $0.64(0.52-0.80)$ & & $0.89(0.71-1.12)$ & \\
\hline \multirow[t]{3}{*}{2} & Marital status & & & $<0.001$ & & 0.046 \\
\hline & No partner & 297 & 1.00 & & 1.00 & \\
\hline & With a partner & 453 & $1.67(1.40-1.98)$ & & $1.19(1.01-1.43)$ & \\
\hline \multirow[t]{4}{*}{2} & $\begin{array}{l}\text { Per capita income in Reais } \\
\text { (Brazilian currency) }\end{array}$ & & & $0.15^{*}$ & & $0.03^{*}$ \\
\hline & $1^{\circ}$ tetcile & 227 & 1.00 & & 1.00 & \\
\hline & $2^{\circ}$ tertile & 254 & $1.08(0.90-1.29)$ & & $1.03(0.89-1.18)$ & \\
\hline & $3^{\circ}$ tertile & 254 & $0.88(0.73-1.06)$ & & $0.83(0.71-0.99)$ & \\
\hline \multirow[t]{3}{*}{3} & Physical activity & & & 0.004 & & 0.22 \\
\hline & Yes & 650 & 1.00 & & 1.00 & \\
\hline & No & 95 & $1.32(1.10-1.59)$ & & $1.10(0.94-1.30)$ & \\
\hline \multirow[t]{3}{*}{3} & Fruit consumption & & & 0.28 & & 0.31 \\
\hline & $\geq 5$ days per week & 311 & 1.00 & & 1.00 & \\
\hline & $\leq 4$ days per week & 439 & $0.92(0.79-1.07)$ & & $1.07(0.94-1.22)$ & \\
\hline \multirow[t]{3}{*}{3} & Vegetable consumption & & & 0.98 & & 0.61 \\
\hline & $\geq 5$ days per week & 410 & 1.00 & & 1.00 & \\
\hline & $\leq 4$ days per week & 340 & $1.00(0.86-1.16)$ & & $1.04(0.89-1.21)$ & \\
\hline \multirow[t]{3}{*}{3} & Problematic use of alcohol & & & 0.69 & & 0.20 \\
\hline & No & 528 & 1.00 & & 1.00 & \\
\hline & Yes & 222 & $0.96(0.79-1.17)$ & & $1.12(0.94-1.35)$ & \\
\hline
\end{tabular}

1 = Distal level; 2 = Intermediate level; 3 = Proximal level. / 1 = Nível distal; 2 = Nível intermediário; 3 = Nível proximal.

* Linear trend p value. / $p$ valor para tendência linear.

$\$$ Adjusted for other variables of the same level or higher with a p value $\leq 0.20 . /$ Ajustada para outras variáveis do mesmo nível ou de nível superior com $p$ valor $\leq 0,20$.

lation of Brazil, other studies using this indicator are necessary, due to the economic and cultural differences that exist between the Brazilian regions, which present a strong association with obesity indices in adults ${ }^{18}$.
Prevalence of central obesity, measured by waist circumference in studies on Brazilian adults is lower than prevalence of this kind estimated by the WHtR in both sexes in this study. In the study on adults from Salvador, 
Bahia $^{25}$, the prevalence of central obesity in women was $35.7 \%$ and in men $12.9 \%$ and in the city of Pelotas, Rio Grande do Sul ${ }^{26}$, prevalence of obesity in women and men was $38.7 \%$ and $18.5 \%$, respectively. However, prevalence in those studies ${ }^{25,26}$ is lower than that found in this study, using high waist circumference. In contrast, the greatest prevalence of central obesity assessed by waist circumference of women in this study corroborates with other Brazilian research ${ }^{25,26,27}$. In addition, prevalence of central obesity in this study exceeds the values observed for obesity, through calculation of BMI in adults from the southern region of Brazil and other regions in the country ${ }^{3}$.

In this study, there was a linear trend of an increase in the prevalence of central obesity with the advance of age in both sexes, as was observed in a study on Japanese adults ${ }^{10,28}$. This phenomenon has been observed both when obesity is measured by $\mathrm{BMI}^{29}$ and when it is measured by central obesity indicators in adults ${ }^{26,30}$. This accumulation of body fat with ageing is characterized as a common process in old age, inherent to different components such as adoption of sedentary behaviors, insufficient practice of moderate to vigorous physical activity and ingestion of high calorie foods. These are in addition to other physiological aspects such as a slowing-down of the metabolism and hormonal alterations, which can contribute to an increase in levels of body adiposity ${ }^{1}$.

No association was observed between health related behaviors and central obesity after multivariable analysis in men and women from Florianópolis. Of the health related behaviors analyzed in women, regular consumption of fruit and problematic use of alcohol lost their association with central obesity after adjusting for sociodemographic indicators, and for men, the practice of physical activity did not remain associated with central obesity. However, the practice of physical activity has been observed as a habit associated with lower central obesity indices ${ }^{31}$. Possibly specific characteristics of the population of Floria- nópolis, such as the adoption of healthy habits like regular consumption of fruit and vegetables and low consumption of fatty meat and fizzy drinks when compared to other Brazilian capitals ${ }^{18}$, may not be discriminators of obesity levels in both sexes. In this study, it was observed that the socio-demographic indicators were strongly associated with central obesity, both when measured by WHtR and by waist circumference.

A study with Brazilian adults from the state of Maranhão identified for both sexes that the socio-demographic factors were discriminators of the central obesity indices (measured by waist circumference) and in a similar way to that observed in this study, the indicators of health-related behaviors lost association with obesity in the multivariate mode ${ }^{27}$. Despite the nonassociation of health-related behaviors, in an intervention study with adults in the United States, regular practice of physical activities and healthy eating were responsible for the reduction in central obesity levels ${ }^{32}$. In a longitudinal study of 21 years on Finnish adults, the practice of physical activity was associated with lower levels of obesity although this relation was only maintained for women after adjusting for confounding variables ${ }^{33}$.

In this study an inverse association was observed between schooling and income with central obesity for women and inverse association of income with central obesity in men after adjusting for other sociodemographic and economic variables. This association characteristic, especially for women, was presented by Gonzales et al. ${ }^{34}$ and Monteiro et al. ${ }^{35}$ in systematic reviews of studies on obesity and the economic situation of adults. The authors of these reviews observed, among men, a positive association between the socioeconomic indicators and the level of obesity. In a cohort study of live births in Pelotas, Rio Grande do Sul, in 1982 and reassessed in $2006^{36}$ the same characteristic was observed i.e. greater prevalence of central obesity observed in men with a better financial situation and, 
contrastively, in women with a worse economic situation ${ }^{36}$.

In this study, women with a higher schooling level presented a prevalence of $37 \%$ lower of central obesity than those with four or less years of formal education. Other studies with adults corroborate the findings of this study, specifically for women ${ }^{26,27,30}$. Level of schooling was not associated with central obesity in men. However, a lower level of schooling may contribute to an increase in obesity as was observed in European countries ${ }^{37}$. Adults with a partner presented prevalence of central obesity higher than those without a partner, even when controlling for age and economic status. This association was also observed in a population-based study with Brazilian adults, in both men and women ${ }^{30}$. Adults with a partner tend to present lower levels of practicing physical activity, especially during leisure time, possibly due to work activities with a heavy weekly schedule which make regular practice of physical activity impractical and which can contribute to an increase in body adiposity.

Possible limitations of this study include the absence of background information, such as the family economic situation in the past, which presents an association with the current level of obesity, as well as the limitation of assuring a temporal relationship between some exploratory variables and the outcome, above all that of the health-related behaviors which preclude to identify possible causality relationships. On the other hand, the positive points that stand out are the high reproducibility of the interviewers to perform the anthropometric measurements, as well as the high response rate in all income stratums, observed after finalization of the study. Comparisons of composition of age, gender, income and schooling of the sample of this study, with the population of the city of Florianópolis in surveys by the Brazilian Institute of Geography and Statistics, indicate similar characteristics $^{12}$.
The information observed in the current study allows us to conclude that central obesity assessed by WHtR was high and associated with demographic and economic indicators in women and men. For women, the highest prevalence of central obesity was observed in advanced ages, lower schooling level, those living with a partner and having lower per capita income. On the other hand, in men, highest prevalence of central obesity was observed in older people, in those living with a partner and who reported lower income. These characteristics were similar when only waist circumference was used as an indicator of central obesity. However, the main difference between the obesity indicators, WHtR and waist circumference, was the estimate of obesity prevalence.

Obesity, especially when central, is strongly associated with morbidity and mortality from chronic diseases ${ }^{4}$. For this reason, there is a need to develop strategies to maintain adequate levels of fat in adults. Considering that obesity represents an important public health problem worldwide, the development of interventions with a focus on an ageing population and a decrease in social inequalities through improvements to schooling and income for the population, represents an important alternative in the prevention, control and eradication of this problem $^{37}$.

\section{Acknowledgments}

The authors thank the Brazilian Institute of Geography and Statistics (IBGE) for their support in the training stage of the study; Professor Dr. Nilza Nunes da Silva from the Departament of Epidemiology, Faculty of Public Health, University of São Paulo, for contributions to the sampling processes; Secretary of Health, Florianópolis for assistance with the operacionalization of the research; staff from the Post-graduate programs in Public Health, Physical Education and Nutrition, Federal University of Santa Catarina who supervised the study. 


\section{References}

1. World Health Organization (WHO). The world health report 2002. Reducing risks, promoting healthy life. Geneva:WHO; 2002.

2. Low S, Chin MC, Deurenberg-Yap M. Review on epidemic of obesity. Ann Acad Med Singapore 2009; 38(1): 57-65.

3. Instituto Brasileiro de Geografia e Estatística. Pesquisa de Orçamentos Familiares 2008-2009. Antropometria e estado nutricional de crianças, adolescentes e adultos no Brasil. Rio de Janeiro: IBGE, 2010. Disponível em http://www.ibge.gov.br/home/. [Acessado em 15 de outubro de 2010]

4. Ashwell M. Obesity risk: importance of the waist-toheight ratio. Nursing Standard 2009; 23(41): 49-54.

5. Cavalcanti CBS, Carvalho SCBE, Barros MVG. Indicadores antropométricos de obesidade abdominal: revisão dos artigos indexados na biblioteca SciELO. Rev Bras Cineantropom Desempenho Hum 2009; 11(2): 217-25.

6. Ashwell M, Hsieh SD. Six reasons why the waist-toheight ratio is a rapid and effective global indicator for health risks of obesity and how its use could simplify the international public health message on obesity. Int $J$ Food Sci Nutr 2005; 56(5): 303-7.

7. Pitanga FJG, Lessa I. Razão cintura-estatura como discriminador do risco coronariano de adultos. Rev Assoc Med Bras 2006; 52(3): 157-61.

8. Haun DR, Pitanga FJG, Lessa I. Razão cintura/estatura comparado a outros indicadores antropométricos de obesidade como preditor de risco coronariano elevado. Rev Assoc Med Bras 2009; 55(6): 705-11.

9. Flegal KM, Shepherd JA, Looker AC, Graubard BI, Borrud LG, Ogden CL et al. Comparisons of percentage body fat, body mass index, waist circumference, and waist-stature ratio in adults. Am J Clin Nutr 2009; 89(2): 500-8.

10. Hsieh SD, Yoshinaga H, Muto T. Waist-to-height ratio, a simple and practical index for assessing central fat distribution and metabolic risk in Japanese men and women. Int J Obes 2003; 27(5): 610-6.

11. Mirmiran P, Esmaillzadeh A, Azizi F. Detection of cardiovascular risk factors by anthropometric measures in Tehranian adults: receiver operating characteristic (ROC) curve analysis. Eur J Clin Nutr 2004; 58(8): 1110-8.

12. Instituto Brasileiro de Geografia e Estatística (IBGE). Contagem da população. Rio de Janeiro: IBGE, 2000. Disponível em http://www.ibge.gov.br/home/. [Acessado em 25 de agosto de 2009]

13. Dean AG, Dean JA, Colombier D, Brendel KA, Smith DC, Burton $\mathrm{AH}$ et al. Epi Info, version 6: a word processing, database, and statistics program for epidemiology on microcomputers. Atlanta, Georgia, USA: Centers for Disease Control and Prevention; 1994.
14. Ulijaszek SJ, Kerr DA. Anthropometrics measurement error and the assessment of nutritional status. Brit J Nut 1999; 82(3): 165-77.

15. Gore C, Norton K, Olds T, Whittingham N, Birchall $\mathrm{K}$, Clough M, et al. Accreditation in anthropometry: an Australian model. In: Norton K, Olds T. (eds.). Anthropometrica. Sydney: University of New South Wales Press; 1996. p. 395-411.

16. Lohman TG, Roche AF, Martorell R. Anthropometric Standardization Reference Manual. Champaign: Human Kinetics Books; 1988.

17. Petroski EL. Antropometria. Técnicas e padronizações. $3^{\mathrm{a}}$ ed. Blumenau: Nova Letra; 2007.

18. Ministério da Saúde do Brasil. Vigilância de Fatores de Risco e Proteção para Doenças Crônicas por Inquérito Telefônico: estimativas sobre frequência e distribuição sócio-demográfica de fatores de risco e proteção para doenças crônicas nas capitais dos 26 Estados brasileiros e no Distrito Federal em 2008. Brasília: Ministério da Saúde; 2009.

19. Jaime PC, Figueiredo ICR, Moura EC, Malta DC. Factors associated with fruit and vegetable consumption in Brazil, 2006. Rev Saúde Pública 2009; 43(S2): 57-64.

20. Lima CT, Freire AC, Silva AP, Teixeira RM, Farrell M, Prince $\mathrm{M}$. Concurrent and construct validity of the audit in an urban Brazilian sample. Alcohol Alcohol 2005; 40: 584-9.

21. Victora CG, Huttly SR, Fuchs SC, Olinto MT. The role of conceptual frameworks in epidemiological analysis: a hierarchical approach. Int J Epidemiol 1997; 26(1): 224-7.

22. Can AS, Bersot TP, Gönen M. Anthropometric indices and their relationship with cardiometabolic risk factors in a sample of Turkish adults. Public Health Nutr 2008; 12(4): 538-46.

23. Mansour AA, Al-Jazairi MI. Cut-off values for anthropometric variables that confer increased risk of type 2 diabetes mellitus and hypertension in Iraq. Arch Med Res 2007; 38(2): 253-8.

24. Lorenzo C, Serrano-Ríos M, Martínez-Larrad MT, Gonzalez-Villalpando C, Williams K, Gabriel R et al. Which obesity index best explains prevalence differences in type 2 diabetes mellitus? Obesity 2007; 15(5): 1294-301.

25. Oliveira LPM, Assis AMO, Silva MCM, Santana MLP, Santos NS, Pinheiro SMC et al. Fatores associados a excesso de peso e concentração de gordura abdominal em adultos da cidade de Salvador, Bahia, Brasil. Cad Saúde Pública 2009; 25(3): 570-82.

26. Olinto MTA, Nácul LC, Dias-da-Costa JS, Gigante DP, Menezes AMB, Macedo S. Níveis de intervenção para obesidade abdominal: prevalência e fatores associados. Cad Saúde Pública 2006; 22(6): 1207-15. 
27. Veloso HJF, Silva AAM. Prevalência e fatores associados à obesidade abdominal e ao excesso de peso em adultos maranhenses. Rev Bras Epidemiol 2010; 13(3): 400-12.

28. Hsieh SD, Yoshinaga H, Muto T, Sakurai Y. Anthropometric obesity indices in relation to age and gender in Japanese adults. Tohoku J Exp Med 2000; 191(2): 79-84.

29. Gigante DP, Moura EC, Sardinha LMV. Prevalência de excesso de peso e obesidade e fatores associados, Brasil, 2006. Rev Saúde Pública 2009; 43(S2): 83-9.

30. Castanheira M, Olinto MTA, Gigante DP. Associação de variáveis sócio-demográficas e comportamentais com a gordura abdominal em adultos: estudo de base populacional no Sul do Brasil. Cad Saúde Pública 2003; 19(S1): 55-65.

31. Hsieh SD, Yoshinaga H, Muto T. Waist-to-height ratio, a simple and practical index for assessing central fat distribution and metabolic risk in Japanese men and women. Int J Obes 2003; 27(5): 610-6.

32. Goodpaster BH, DeLany JP, Otto AM, Kuller L, Vockley J. Effects of diet and physical activity interventions on weight loss and cardiometabolic risk factors in severely obese adults: a randomized trial. JAMA 2010; 304(16): E1-8.
33. Yang X, Telama R, Viikari J, Raitakari OT. Risk of obesity in relation to physical activity tracking from youth to adulthood. Med Sci Sports Exerc 2006; 38(5): 919-25.

34. González D, Nazmi A, Victora CG. Childhood poverty and abdominal obesity in adulthood: a systematic review. Cad Saúde Pública 2009; 25(S3): 427-40.

35. Monteiro CA, Moura EC, Conde WL, Popkin BM. Socioeconomic status and obesity in adult populations of developing countries: a review. Bull World Health Organ 2004; 82(12): 940-6.

36. González D, Nazmi A, Yudkin JS, Victora CG. Life-course socio-economic factors, skin colour and abdominal obesity in adulthood in a Brazilian birth cohort. Public Health Nutr 2009; 12(11): 2225-35.

37. Roskan AR, Kunst AE, Oyen HV, Demarest S, Klumbiene J, Regidor E, et al. Comparative appraisal of educational inequalities in overweight and obesity among adults in 19 European countries. Int J Epidemiol 2010; 39(2): 392404.

Received: $18 / 08 / 10$

Final version: $28 / 10 / 10$

Approved:12/11/10 